Submission to Women's Economic Empowerment Special Issue: Journal of Indian Ocean Region, August 2016

\title{
The Future of Women's Economic Empowerment in the Indian Ocean Region: Governance Challenges and Opportunities
}

Associate Professor Susan Harris Rimmer, Australian Research Council Future Fellow, Griffith Law School, Law Futures Centre, Griffith University, Nathan, Queensland. ${ }^{1}$ E; s.harris-rimmer@griffith.edu.au

\begin{abstract}
This paper seeks to explore the prospects for women's economic empowerment in the Indian Ocean region, bringing a feminist global governance perspective to the priority Trade and Investment Facilitation and Tourism areas of the Indian Ocean Rim Association's work. Why would investing in women's economic empowerment bring benefits to one billion women living in the IORA region, and how could such investment also benefit twenty IORA economies?

Part I outlines the links between women's economic empowerment and overall sustainable macroeconomic growth that reduces inequality. Part II sets out some of the ideas that have been developed about paths to women's economic development in other governance fora, or through the research of international organisations. Case studies are provided of trade in textiles, and tourism as a service industry. Part III notes some of the challenges IORA's leadership may face in pursuing this agenda.
\end{abstract}

I argue that this is an area of great opportunity for IORA, and a test of whether the organisation is capable of setting governance and regulatory standards expected of modern regional organisations.

\section{Key Words}

Indian Ocean Rim Association; gender equality; governance; women’s economic empowerment; trade; tourism

\footnotetext{
${ }^{1}$ The author was a participant at the IORA Dialogue Event held in Kuala Lumpur from 18-20 August 2014. This paper reflects only the author's views and all errors remain my own.
} 


\section{The Future of Women's Economic Empowerment in the Indian Ocean Region: Governance Challenges and Opportunities}

\section{Introduction}

This paper seeks to explore several questions that should be of significance to the leadership of the Indian Ocean Rim Association (IORA). Why would investing in women's economic empowerment bring benefits to one billion women living in the IORA region and how could such investment also benefit twenty IORA economies? What are some of the ideas that have been developed about paths to women's economic development in other governance settings or through the research of international organisations? What are the links between women's economic empowerment and overall sustainable macroeconomic growth that reduces inequality?

The definition of women's economic empowerment used in this paper has two elements. ${ }^{2}$ The first is 'Women's Economic Advancement', meaning economic success and gain for individual women and groups of women based on the skills and resources necessary to compete in markets, plus fair and equal access to economic institutions; and second 'Women's Power and Agency', meaning the ability of women to take and act on decisions, and control their own resources and profits.

IORA has made initial steps to consider women's economic empowerment at the governance level. Established in 1997, the IORA Ministers agreed to six priority areas of cooperation in 2011 (see Figure 1: Map of IORA members). These are: maritime safety and security, trade and investment facilitation, fisheries management, disaster risk management, academic and science \& technology cooperation, and tourism and cultural exchanges.

The IORA Perth Communiqué 2013 states at paragraph 19:

The empowerment of women and girls in the region is a high priority for IORA.

\footnotetext{
${ }^{2}$ There is no accepted definition of women's economic empowerment in international law as yet, and there are a variety of ways the phrase is used by the UN, the OECD, the World Bank and states. The definition used in this paper using the two elements of success and power is based on the report by the International Center for Research on Women by Ann Marie Gollo, Anju Malhotra, Priya Nanda and Rekha Mehra, Understanding and Measuring Women's Economic Empowerment: definition, framework and indices (2011, Washington). They state at p. 4: "A woman is economically empowered when she has both the ability to succeed and advance economically and the power to make and act on economic decisions.”
} 
This was because the empowerment of women and girls in the region was identified as an important cross-cutting issue for two reasons cited on the IORA website:

'.. women have been important contributors to the economic and social development of the countries in the region - a fact that needs to be acknowledged and strengthened within the Association in the future'.

'Empowering women and girls is regarded as an essential part of the solution to some of the most serious global challenges of today: food security, poverty reduction and sustainable development' (IORA 2016).

IORA countries are very diverse, but they have one thing in common. They are seeking sustainable macroeconomic growth and further cooperation. Women's economic participation and agency is one source of macroeconomic growth as per the aims of IORA, and a source of cultural exchange. I consider these issues in relation to the two IORA priorities of trade and investment facilitation; and tourism and cultural exchanges.

\section{Figure 1: IORA Members}

\section{$<$ insert map $>$}

Part I outlines the links between women's economic empowerment and overall sustainable macroeconomic growth that reduces inequality. Data snapshots are provided for IORA countries in relation to gender equality indicators, trade, tourism and gross national income (GNI). Four maps are provided; showing the variance in gender inequality, gross national income, female labour participation and female population.

Part II sets out some of the ideas that have been developed about paths to women's economic development in other governance settings or through the research of international organisations. The benefits of and barriers to women's economic empowerment and agency globally are summarised. Part III notes some of the challenges IORA's leadership may face in pursuing this agenda. As 'womenomics' took the world by storm in 2009, IORA looked decidedly old-fashioned with its lack of female representation and neglect of gender policy. Economic governance should reflect the citizenship of its member states, and it is proven that diverse teams make better decisions. ${ }^{3}$ At the same time, IORA Leaders are looking for new pathways to growth, and the headline-stealing economic benefits unlocked by investing in women should make for a persuasive case to IORA decision-makers. The 'size of the prize'

\footnotetext{
${ }^{3}$ See further Galinsky et al 2015; and Lückerath-Rovers 2013.
} 
for IORA economies for investing in gender equality in growth terms is very large, as is the potential for more sustainable and equal growth. A new McKinsey report puts the figure at US $\$ 12$ trillion extra GDP by 2025 by simply giving more women the same opportunities as men (Woetzel et al 2015).

\section{Tourism and Trade: Opportunities for Gender Initiatives}

This growth potential is obvious in case studies chosen for this paper, specifically tourism as a service industry and trade in textiles. Both sectors make significant contributions to economic activity throughout the IORA grouping. Women are active in both sectors, especially as workers, and have the capacity to scale-up their participation. Tourism is a service industry and often a source of foreign currency. It is a focus for IORA due to the common factor of shared access to the Indian Ocean, and the potential for further cooperation and growth. In 2015, tourism contributed 9.8\% of world GDP (US\$7.2 trillion) and accounted for 284 million jobs (WTTC 2015). Over the next ten years this industry is expected to grow by an average of $4 \%$ annually, taking it to $10 \%$ of global GDP. By 2022, it is anticipated that travel and tourism will account for 328 million jobs; or 1 in every 10 jobs on the planet (WTTC 2012). Tourism is an industry that has potential to promote the production of local textiles, the protection of heritage sites, and other goods and services that enhance national identity and the broader 'creative economy'. The data presented in Table 1 relates to rates of international arrivals, but there is also considerable economic contribution made by domestic tourism.

Trade must be a key area of concern for IORA given its geographic and historic trade routes. All nations, including Australia, state that they desire an open, predictable, nondiscriminatory, and rule-based multilateral trading system centred on the World Trade Organization (WTO). Yet the universal consensus is that the trade system is in deep trouble. The nature of trade itself is changing, the contribution of trade to macroeconomic growth is changing; and the multilateral system is under challenge in terms of trade governance. IORA must work harder to make an impact on the trade agenda, and working harder on 'behind the border' reforms that benefit women could be a way forward. This means we must think about gender issues in relation to a trade agenda which is changing rapidly.

\section{Trade Governance}

The DNA of trade is changing, with most trade experts urging reforms to the WTO in order to adapt to the new world of global value chains, integrated global standards, and 
transnational investment flows. As Nancy Pelosi, Minority Leader of the United States (US) House of Representatives, recently stated when describing the Trans-Pacific Partnership:

In order to succeed in the global economy, it is necessary to move beyond stale arguments of protectionism versus free trade ...

Today, driven by a new technological revolution, national markets are being transformed into global networks of finance, production and distribution. Markets - for goods, money and even labor — are integrating across borders beyond the reach of national legislative bodies. (Pelosi 2015)

John Ravenhill has found that international trade increasingly represents trade in components as part of the production of a product. With global manufacturing, goods are now 'made in the world' rather than in a single country. Ravenhill points out that one implication of the rise in global value chains is that traditional trade statistics, which are measured on a gross basis rather than value-added, may be obsolete, and so 'concern over bilateral trade imbalances is clearly misplaced' (Lowy 2013). Traditional trade policy is no longer an effective tool to assist domestic industries either, according to Austrade Chief Economist, Mark Thirwell (Lowy 2013). Trade in services is a crucial area of liberalisation according to almost all economists, but as we enter into a service and knowledge-driven economy this area of negotiations has proven particularly slow and difficult.

The fundamentals of trade are changing. Global trade is growing slower than global production. Trade growth numbers of 3.1 per cent in 2014 and 4 per cent in 2015 may be greater than those of recent years, but they remain significantly lower than long-term average growth rates (Dadush 2015). Trade deals now often deal with regulatory compatibility between nations (harmonisation or mutual recognition) rather than tariff preferences. This includes areas like product standards that more directly affect consumers.

The geo-politics of trade are changing. As the WTO reaches its twentieth anniversary, many member countries are worried about a clash among blocs such as the BRICS (Brazil, Russia, India, China, South Africa) versus the OECD (Organisation of Economic Cooperation and Development) nations. They sometimes face backlash from citizens against some globalisation impacts. Important global trade negotiations stall while regional preferential trade agreements proliferate, often likened to noodle bowls or spaghetti. ${ }^{i}$ The WTO website lists 282 Regional Trade Agreements in force as of 5 March 2013, and the figure is rising (WTO 2015). 
There are some bright spots on the multilateral trade agenda. A historic WTO agreement on Trade Facilitation reached in December 2013 in Bali aims to make it easier and cheaper for goods to flow through the ports and customs processes of 160 countries. Just before the G20 Brisbane Summit, the US and India reached a deal that allowed leaders to commit to implement all elements of the Bali package and in June 2015, Australia formally accepted the Agreement on Trade Facilitation. On full implementation, it is estimated it may increase global GDP by US\$1 trillion per annum and create 21 million jobs.

WTO Director-General Robert Azevêdo has opened conversations on the future of the 'negotiating pillar' of the WTO: the rules that govern decision-making in the body (Azevedo 2014). G20 leaders subsequently agreed to discuss ways to make the multilateral trading system work better (G20 Turkey, 2015). APEC’s decision to liberalise trade in environmental goods and services has been broadly welcomed.

Of course, the WTO has the same great power leadership issues that beset the rest of the multilateral system. The 'emerging economies' are no longer emerging, but have arrived. According to data from the International Monetary Fund (IMF), the combined gross domestic product (GDP) of the top seven emerging nations is now bigger than those of the conventional Group of Seven industrialised nations when measured in terms of purchasing power parity. The contours of power are almost unrecognisable from 2001 to the present day. In this setting, IORA needs to be creative to make a contribution to trade governance. One opportunity is to focus on improving trade governance and access in certain sectors, and a key area for IORA could be trade in textiles. The total value of textiles exports (fashion, carpets, yarn and wicker-ware) in Indian Ocean Rim economies in 2011-2012 was estimated at $\$ 5.5$ billion (DFAT 2014).

We can think about textiles in a variety of ways in this context: as the expression of cultural and national identity; as part of a production chain that leads to clothing, homewares and other value-added goods; as textiles for export as part of international trade in merchandise; or for sale at a local village market stall. Women participate in textiles industries in the IORA grouping in a wide spectrum of roles: as artisans and artists, workers in garment factories, fashion designers, owners of small to medium enterprises (SMEs), exporters and importers, officials and regulators. In 2011, trade in exports of clothing and textiles contributed over \$US706 billion to the global economy. Several IORA countries are major exporters of textiles and clothing. 
Finally, IORA is a region that has at least four distinct attributes that make this examination of gender equality significant.

- $\quad$ The region holds over 2 billion people, with over a billion women and girls.

- It is a region that has been woven together by trade routes and sea-lanes for hundreds of years.

- It is still the centre of world trade — with the Indian Ocean hosting half the world's container ships at any one time.

- It is a site of immense cultural diversity.

I argue that this region deserves special attention to gender equality issues at a governance level for IORA to become an important regional actor. The IORA grouping could consider advocating for the next round of reforms at the World Trade Organisation to focus on domestic actions designed to boost women's participation in trade, particularly services such as tourism and trade in textiles.

\section{Key IORA data}

Data and rankings are provided for IORA countries about the overall conditions of life for women in Table 1 (Appendix A). Notably UN Women has created a baseline study to track gender data over time (Marston 2015). Female populations in IORA are represented visually in Map 2.

\section{Figure 2: 2013 Percentage of Population and Total Female Populations}

$<$ insert map $>$

Gender Inequality Indicators are provided by reference to data from the United Nations Development Program Human Development Report. The Gender Inequality Index relies on data from major publicly available databases, including

- the maternal mortality ratio from the United Nations Maternal Mortality Estimation Group (MMEIG), the WHO, UNICEF, UNFPA and the World Bank;

- adolescent fertility rates from the UN Department of Economic and Social Affair's World Population Prospects;

- educational attainment statistics from the UNESCO Institute for Statistics educational attainment tables and the Barro-Lee data sets;

- parliamentary representation from the International Parliamentary Union; and 
- labour market participation from the International Labour Organization's Key Indicators of the Labour Market (KILM) 7th Edition.

The world average score on the GII is 0.463 , reflecting a percentage loss in achievement across the three dimensions due to gender inequality of 46.3 per cent.

Figure 3: IORA Gender Equality Index 2012

$<$ insert map $>$

Trade Flows

Table 1 seeks to represent overall trade flows by IORA countries, based on World Bank data. There are some figures for trade in textiles and clothing, but we are looking broadly at merchandise trade as a share of GDP (which is the sum of merchandise exports and imports divided by the value of GDP in 2012 \$USD).

We cannot yet present data on trade flows in particular goods or services across the IORA region, but this is a useful ambition for IORA.

\section{Tourism Activity}

This data in Table 1 is sourced from the World Bank and looks at international arrivals (airports, ports, land borders) in IORA countries in 2010. There is also domestic and regional tourism not captured by this data.

\section{Gross National Income}

Gross national income is a measure most are more familiar with, but has a gender impact because it does not generally include unpaid care work, which is undertaken mainly by women all around the globe. The variation between IORA members is stark.

Figure 4: IORA GDP 2012

$<$ insert map $>$

\section{Female Labour Force Participation Rates}

This is an important area to be concerned with data and evidence, as it is key to arguments about economic growth for the nation as a whole, so we have pulled it out of the general focus on gender inequality. Our map is based on data collected by the World Bank (World Development Indicators, 2013), and the Key Indicators of the Labour Market (KILM) 7th Edition. 
Figure 5: Female Labour Participation Map

$<$ insert map $>$

\section{Part II: Women's Economic Empowerment: Benefits and Barriers}

The World Bank has identified that the common constraints facing many women in participating in the formal economy include lack of mobility, time due to unpaid care work, skills, exposure to violence, and the absence of basic legal rights (2012). All economic data tells us that tourism is a source of growth, trade, especially in clothing is a source of growth, and that investing in women is a source of growth, as well as a fulfilment of human rights and social potential.

\section{Benefits}

Women make up a little over half the world's population, but their contribution to measured economic activity, growth, and well-being is considered by mainstream economic institutions to be below its potential. This has led to the inclusion of gender-specific targets and indicators in the newly agreed 17 Sustainable Development Goals as part of the 2030 Development Agenda (Goals 5, 8 and 10 in particular). There is settled research that focusing on women in development and poverty-reduction programs had overall benefits for the target community.

There is also international legal commitment through treaty law to the rights and status of women. The Convention for the Elimination of All Forms of Discrimination Against Women (CEDAW) was adopted by the UN General Assembly in 1979 and now has 187 state parties. All IORA states have signed except Iran. The Convention contains a broad definition of discrimination in Article 1, covering both equality of opportunity (formal equality) and equality of outcome (de facto or substantive equality):

[D]iscrimination against women violates the principles of equality of rights and respect for human dignity, is an obstacle to the participation of women, on equal terms with men, in the political, social, economic and cultural life of their countries, hampers the growth of the prosperity of society and the family and makes more difficult the full development of the potentialities of women in the service of their countries and of humanity.

The Convention requires states to take legal and other measures to ensure the practical realisation of the principle of sex equality (Article 2). The Convention covers a broad range 
of areas where state parties must work to eliminate discrimination. ${ }^{4}$ Article 4 allows for affirmative action, in the form of temporary special measures designed to accelerate de facto equality such as quotas in employment, education, financial services and politics to overcome historical barriers. Despite this, the World Bank found recently that in 100 economies, women face gender-based job restrictions under the law. Most IORA members have significant legal barriers to women's participation in work and public life (World Bank 2016).

The major global economic institutions have been providing evidence since 2006 that when women are able to develop their full labour market potential, there can be significant macroeconomic gains for the nation (Elborgh-Woytek et al, 2013). Some studies have put the figure as high as a 27 percent increase for some regions (Aguirre et al 2012). It is not just the quantum of growth that interests economists but the quality of the growth.

The World Development Report 2012: Gender Equality and Development released by the World Bank urged states to close differences in access to economic opportunities and the ensuing earnings and productivity gaps between women and men. The Bank advocates increasing access to child care and early childhood development, and investing in rural women (World Bank 2012). These are social policy recommendations, but driven by an economic growth goal.

These World Bank studies usually focus on the potential of female labour force participation. Between 1980 and 2008, 52 million women joined the labour force, which equates to 52 percent of all workers globally. Men’s participation rates declined from 82 percent in 1980 to 78 percent in 2008. ${ }^{5}$ The rise in female labour force participation can be attributed to rising education levels, economic development, anti-discrimination measures \& declining fertility rates.

'Womenomics' is posited to have several overall macro benefits:

- Some argue that higher female work force participation would also result in a more skilled labour force, in view of women's higher education levels (Steinberg and Nakane, 2012).

\footnotetext{
${ }^{4}$ These provisions include political and public life (Article 7), international organisations (Article 8), education (Article 10), employment (Article 11), health care (Article 12), financial credit (Article 13b), cultural life (Article 13c), the rural sector (Article 14), the law (Article 15) and marriage (Article 16).

${ }^{5} \mathrm{~A}$ visual representation can be seen here: http://go.worldbank.org/9V87N19PJ0
} 
- Studies have shown that women in developing countries are more likely than men to invest a large proportion of their household income in the education of their children. According to the International Labour Organisation (ILO), women’s work, both paid and unpaid, may be the single most important poverty-reducing factor in developing economies (Heintz, 2006).

- The benefits can be very large in scale. Detailed studies have modelled that increasing the female workforce participation in developed economies such as Australia, using the same policy measures that our comparator Canada has successfully implemented (tax, welfare reform and affordable childcare), would add \$AUD25 billion to Australia's gross domestic product (Grattan 2012: 22).

There is significant evidence that supports the formal and informal education of women and girls as the foundation for women's participation in the formal economy in the longer term. As the Australian Minister for Women Michaelia Cash stated at the United Nations in 2014: "Education is the anti-poverty vaccine for women". 6

Other benefits of women's economic empowerment for economic governance need more research. The employment of women on an equal basis should allow companies to make better use of the available talent pool, with potential growth implications (Barsh and Yee, 2012). There is evidence (contested) of a positive impact of women's presence on boards and in senior management on companies’ performance. Companies employing female managers are likely to be better positioned to serve consumer markets dominated by women (OECD 2012).

There might also be better corporate governance (OECD 2012) and risk management (Coates and Herbert, 2008) from more diversity on boards. As IMF head Christine Lagarde famously said: "Gender-dominated environments are not good... particularly in the financial sector where there are too few women. In gender-dominated environments, men have a tendency to... show how hairy chested they are, compared with the man who's sitting next to them. I honestly think that there should never be too much testosterone in one room' (Lagarde 2011).

\section{Barriers}

Despite these benefits, female labour force participation has remained lower than male participation, and in several nations, the rates are in decline. Where women are represented, it is not at leadership levels. UN Women found that in 'most Indian Ocean Rim Member States,

\footnotetext{
${ }^{6}$ Remarks at the UN Commission for the Status of Women 58 side event, March 2014.
} 
women are significantly underrepresented in management, senior management and leadership positions in the private sector, cooperatives and trade unions' (Marston 2015: 20).

Barriers to women's economic empowerment include the following:

- Women do the majority of unpaid work especially in areas of care and domestic labour.

- When women are employed in paid work, they are overrepresented in the informal sector with temporary or precarious working arrangements.

_ Women also face significant wage differentials vis-à-vis their male colleagues.

- In many countries, legal, social and cultural barriers to joining the labour market restrict women's options for paid work.

- Female representation in public and private sector leadership positions and on boards, as well as rates of female entrepreneurship remains low.

- Women are in occupational segregation with high risk during transition to international markets - women are concentrated in sectors, industries, occupations, and jobs with lower average productivity.

- Women often have lower level education and literacy rates.

- Women often do unpaid work rarely gets recognition at a societal level.

- Women experience more obstacles in accessing land, financial services, technology, information, other productive resources, and markets.

- Approximately one in three women experience violence in their private and public lives.

The UN Women report found significant evidence of these barriers in IORA member countries in its 2015 study.

\section{Trade barriers}

Evidence shows that international trade tends to increase the availability of formal but mostly low-skilled, labour-intensive and low value-added jobs in developing countries, with most of these jobs in export-oriented having been filled by women in recent decades. Many women are also involved in informal trade.

The UN states:

Measures such as access to credit, social safety nets - such as health insurance transport, foreign currency exchange, infrastructure for storage of goods, refrigeration of 
agricultural commodities and transport facilities, as well as access to health care, water and sanitation facilities and security services, and training of customs and police officers about women's rights, would greatly improve informal traders' activity and enhance their contribution to wealth creation and poverty reduction.(UN Womenwatch 2011)

The UN has found that important structural barriers are preventing women to benefit from trade-orientation; these include: women and girls' limited access to education and skills, including in cutting-edge educational fields; de jure and de facto discrimination against women in the control over economic and financial resources, productive assets and access to financial services; and women’s limited access to new technologies for production, training, information and marketing.

Trade policy should thus consider how it can enable women to become key actors in those sectors of the economy that benefit most from trade; it should provide development pathways for women into more technologically advanced and dynamic sectors of the economy; and account for the likely effects of widening or closing the gender wage gap and reducing women's time poverty.

The UN women report on IORA found that:

\footnotetext{
Women entrepreneurs are on the rise in many Indian Ocean Rim countries and could make an important contribution to national economies. Countries that have not yet created enabling environments to support women entrepreneurs would greatly benefit from doing so. While women make important contributions to a range of supply chains across Indian Ocean Rim economies, significant efforts are still needed to better integrate them into these chains and move them into higher value-added production and decisionmaking positions (Marston 2015: 20).
}

\section{Tourism barriers}

According to the Global Report on Women in Tourism, tourism is one of the world's largest generators of wealth and employment, and provides a wide range of income-generation opportunities for women, particularly in developing regions. Women are almost twice as likely to be employers in tourism as compared to others sectors. Tourism also offers leadership possibilities, with women accounting for one in five tourism ministers worldwide; more than in any other branch of government. 
Nevertheless, women are often concentrated in low-skill, low-paid and precarious jobs, typically earn $10 \%$ to $15 \%$ less than their male counterparts, and tend to perform jobs such as cooking, cleaning and hospitality (UN Women 2010) which conform to societal roles for many cultures.

The next section examines what other comparator governance forums are doing to deal with similar challenges in their membership.

\section{Part III Governance solutions to increase women's economic empowerment and macroeconomic growth}

This Part outlines the current measures being undertaken by comparator governance groupings that have a similar focus on economic growth. Groupings that have some overlap with IORA in terms of diverse groupings include APEC, the G20 and MIKTA.

\section{Asia-Pacific Economic Cooperation}

APEC Women and the Economy Forum since 1998 and has created a Policy Partnership on Women and the Economy. t APEC Ministerial Meeting on Women held in Manila in 1998, which paved the way for the drafting of the Framework for the Integration of Women in the APEC agenda. The Framework has guided all APEC fora in integrating gender equality and women's economic empowerment into APEC processes and activities. It also considers progress made by all successive meetings on women and the economy up to 2015, and recognizes the five year anniversary of the 2011 San Francisco Declaration at the High Level Policy Dialogue on Women and the Economy. There is also a need for good diagnostic data to encourage governments to improve outcomes, such as the APEC women and the economy dashboard. The G20 should also showcase good gender practice and the good practices of women and men; companies and government programs committed to gender inclusive growth. Another APEC example is focused on increasing the numbers and success of female entrepreneurs

\section{The APEC Private-Public Dialogue on Women and the Economy}

Mexico, Indonesia, Korea, Turkey, Australia (MIKTA) 
MIKTA is a relatively new grouping of foreign ministers from five systematically important economies, which began in September 2013. MIKTA sees itself as a 'cross-regional consultative platform' which aims to be a 'bona fide enabler in terms of providing global public goods' through global governance reform. ${ }^{7}$

The MIKTA group releases joint declarations such as

9. We agreed to work together to promote gender equality by advocating in our respective regions broader acceptance of the commitment to reduce the gender gap in employment by 25 per cent by 2025, taking into account national circumstances. We will also encourage gender equality across the spectrum of MIKTA activities. (MIKTA 2015)

The Group of 20

The G20 has made incremental progress on gender equality issues as the 'premier forum for macroeconomic cooperation'. The G20 leaders have committed to:

- helping achieve progress on the G20's commitments to 'women's full economic and social participation', which was made in the Los Cabos Leaders' Declaration in $2012^{8}$

- 'women's financial inclusion and education', which was made in the St Petersburg Leaders' Declaration in $2013^{9}$, and the Women's Finance Hub. The Global Partnership for Financial Inclusion and the G20 Financial Inclusion Indicators initiated in Seoul were launched in $2012 .{ }^{10}$

\footnotetext{
${ }^{7}$ Mr. Yun Byung-se, Minister of Foreign Affairs, the Republic of Korea; Mr. José Antonio Meade Kuribreña, Secretary of Foreign Affairs of Mexico; Ms. Retno L. P. Marsudi, Foreign Minister of Indonesia; Mr. Mevlüt Çavuşoğlu, Minister of Foreign Affairs of Turkey; and Ms. Julie Bishop, Minister of Foreign Affairs and Trade of Australia, 2015. Opinion Editorial: '21st Century Global Governance: Rise of the Rest - Cross-regional Networks', 7 January 2015, available at http://foreignminister.gov.au/articles/Pages/2015/jb_ar_150107.aspx?ministerid=4 ${ }^{8}$ G20, G20 Mexico Leaders' Declaration, Los Cabos, $18-19$ June 2012, available at http://g20watch.edu.au/g20-leaders-declaration-los-cabos-2012.

${ }^{9}$ G20, G20 Russia Leaders’ Declaration, St Petersburg, 5 September 2013, available at http://www.mofa.go.jp/files/000013493.pdf.

${ }^{10}$ Available at http://www.gpfi.org/about-gpfi
} 
- 'reducing the gap in participation rates between men and women by 25 per cent by 2025', which was agreed on in the Brisbane Leaders' Declaration in 2014, and which would, if implemented, create 100 million new jobs for women. ${ }^{11}$

Like APEC, G20 Leaders have established official second track processes to aid their deliberations. Under the 2015 Turkish G20 Presidency, the W20 engagement group was officially established to provide policy advice to G20 Leaders. ${ }^{12}$ It was launched in Ankara on 6 September 2015 and the first summit took place on 15-16 October 2015. The Istanbul W20 communiqué made recommendations in areas of empowering women through strengthening linkages between education, employment and entrepreneurship; increasing the number of women in leadership positions; ensuring women's access to finance; and supporting women's networks and women owned enterprises. 13 The 2015 process was influenced by an open poll and delegate submissions, and proposed a monitoring system for future W20 Summits.

China continued Turkey's investment in the W20 in 2016, chiefly through the W20 Summit in Xi'an where the representatives of G20 countries and invited guests agreed a communiqué to be presented to the G20 Leaders in the lead-up to the September 2016 Hangzhou Summit. China had some experience in this area having held a successful APEC Women in the Economy Forum in 2015 with discussions on women and green development, as well as women and regional trade. The All-China Women's Federation hosted the 2016 W20 Summit with a keynote speech by China's Vice President, Li Yuanchao. Li opened the summit in Xi'an on 26 May 2016 and his speech demonstrated the increasing legitimacy of the gender and growth agenda, which the Chinese term 'She-Power':

"It is all the more important to pool women's wisdom and strength at a time when the global economic recovery remains fragile. As the Chinese economy moves into a

\footnotetext{
${ }^{11}$ G20, G20 Australia Leaders’ Communiqué, Brisbane, 15-16 November 2014, http://www.g20australia.org/sites/default/files/g20_resources/library/brisbane_g20_leaders_summit_communiq ue.pdf.

12 Susan Harris Rimmer, "Why the W20? Reasons to Take the Newest G20 Social Partner Seriously”, 10 November 2015, http://www.usak.org.tr/en/usak-analysis/comments/why-the-w20-reasons-to-take-the-newestg20-social-partner-seriously.

${ }^{13}$ W20, Women's Summit Communiqué, G20 Turkey, Istanbul, 17 October 2015, http://www.g20.utoronto.ca/2015/151017-w20.html.
} 
New Normal, efforts are made to encourage mass innovation and entrepreneurship, and women are essential in this endeavour.”14

The G20 itself and the engagement groups are supported by the international financial institutions. The IMF and OECD have been exceptionally supportive of the W20, as has UN Women (an entity responsible for promoting women's empowerment and gender equality) and the International Labour Organisation. For example, the OECD held a panel in June 2016 on the G20 labour gap target. ${ }^{15}$ These organisations are also involved with a new initiative called the High Level Panel on Women’s Economic Empowerment, led by UN Women, funded by Canada and the United Kingdom. The inaugural meeting of the Panel was held on 15 March 2016 in the UN headquarters in New York. The Panel is expert and not country based.

Ideas for IORA

IORA could create a more specific version of this, such as an 'Expert group on IORA Women in Trade', or an 'Expert group on Women in Tourism'. Alternatively, each existing national trade advisory group or tourism council to nominate a female member to liaise with a new IORA network.

- IORA countries could consider appointing national champions and special IORA envoys for women's entrepreneurship (based on Sweden).

- Australia could consider a special envoy for women's entrepreneurship, with initial Indo-Pacific focus to assist the Ambassador for Women \& Girls.

- The IORA Grouping could create new awards:

- $\quad$ IORA awards for Women in Business - Tourism and Trade categories

- IORA Creative Economy Awards

- $\quad$ Awards for government agencies in IORA who show most initiative in encouraging women to navigate the regulatory environment

\footnotetext{
14 “Full text of Vice-President Li Yuanchao’s Remarks at Opening Ceremony of W20 Meeting in Xi'an”, China Daily, 25 May 2016 (updated 26 May 2016), http://www.chinadaily.com.cn/china/201605/26/content_25474918.htm.

${ }^{15}$ OECD Forum, “Closing the Gender Gap: 25 by 2025”, http://webcastcdn.viewontv.com/client/oecd/forum2016/video_33304388ad3a42c49a38e79179ffe46e.html
} 
- The IORA Grouping could support advocacy platforms of women informal traders for promoting an enabling environment for their business and access to better services.

\section{Part III Challenges to IORA's leadership}

The IORA Council of Ministers' meeting in Perth, Australia in October 2014 struggled to follow up its commitment to gender issues from the 2013 Communique. The diversity of the membership is an obvious challenge, but other groupings like MIKTA, APEC and the G20 have the same issues with diversity. IORA members could acknowledge in future official documents that there is broader foundation for women's economic empowerment, and that overall IORA countries could strive to improve the employment conditions, access and quality of jobs including in the informal economy and promote family-friendly policies and workplace practices to ensure that both women and men are able to maximize their productivity, and have access to social protection benefits.

IORA leaders should also be sending a clear signal that investing in over a billion women in the IORA region could lead to sustainable growth. The IORA website sets the policy parameters leaders can consider:

IORA may consider the development of a framework for integrating gender perspectives in its programmes and activities and supporting gender analysis and equality in view of scaling up its efforts to close gender gaps, enhance economic growth and strengthen the sustainability of development initiatives undertaken within the region. It is envisaged that within all future project proposals along the six priority areas of the Association, empowerment of women should receive consideration as an important contributor to reducing unemployment and for the subsequent alleviation of poverty in the region.

Education is emphasised as key to women's empowerment. It expands women's opportunities, enhances their capacity to develop their full potential and contributes to more equal gender relationships. IORA should support initiatives and efforts in the education sector that serve to promote women's education in the fields of science and technology and arrangements for training programmes for the empowerment and capacity-building of women in the region should receive attention within each priority area indicated above. There is also a need to strengthen women's economic 
capacity through education and training in business and entrepreneurship. Policy reforms aiming at removing barriers to women's ownership and leadership should be promoted.

Gender-sensitive databases and systems may also be developed to consolidate women's knowledge and experience in sustainable resource use and management.

IORA may collaborate with other regional and international organisations working in the area of gender which could provide constructive strategies, insights and experiences and also allow the harmonisation of policies, approaches, and analytical tools for gender mainstreaming with these institutions. Collaboration with these institutions would enable the development of mechanisms for sharing information. In this regard, IORA may create a platform for sharing of experiences and strategies on gender mainstreaming and also for capturing fully the resources and efforts directed at gender mainstreaming and women's empowerment. Stakeholder participation and policy dialogue are important to enhance the integration of gender in the works of the Association.

\section{Data/Research}

- The IORA Grouping could support countries in collecting and analysing sexdisaggregated data, including those related to informal traders, and on designing appropriate questionnaires and evaluating the information gathered.

- The IORA Grouping could support the development of research from the private or public sector on gender diversity in public and private sector leadership positions in the IORA region.

- The IORA Grouping could strengthen public-private collaboration, including through the exchange and dissemination of best practices domestically and with other IORA economies to share knowledge on effective strategies, to encourage positive action, which promote women's participation in decision-making and leadership roles.

- The IORA Grouping could promote the development of mechanisms which encourage transparency and disclosure of gender diversity in the public and private sectors in IORA countries 
- The IORA Grouping could establish a baseline for data on women in formal trade and/or tourism in IORA countries - using a participatory methodology to explore what women themselves identify as hurdles to their participation in the formal economy.

\section{Conclusion}




\section{Appendix A}

Table 1: IORA by the numbers

\begin{tabular}{|c|c|c|c|c|}
\hline & $\begin{array}{c}\text { GDP per } \\
\text { capita } 2012\end{array}$ & $\begin{array}{c}\text { Tourism - } \\
\text { International } \\
\text { Arrivals } 2010\end{array}$ & $\begin{array}{c}\text { Trade in } \\
\text { Merchandise } \\
\text { WTO } 2012\end{array}$ & $\begin{array}{c}\text { Gender } \\
\text { Inequality } \\
\text { Index } 2012\end{array}$ \\
\hline Australia & 34,548 & $5,885,000$ & 33.8 & $0.115 /$ rank 2 \\
\hline Bangladesh & 1,568 & 303,000 & 51.1 & 0.518/rank 146 \\
\hline Comoros & 980 & 15,000 & 54.5 & Rank 169 \\
\hline India & 3, 203 & $5,776,000$ & 42.1 & 0.61/rank 136 \\
\hline Indonesia & 4, 094 & $7,003,000$ & 43.2 & 0.494/rank 121 \\
\hline Iran & 10.462 & $2,938,000$ & 30.2 & 0.496/rank 76 \\
\hline Kenya & 1,507 & $1,470,000$ & 55.7 & 0.608/rank 145 \\
\hline Madagascar & 853 & 196,000 & 46 & Rank 151 \\
\hline Malaysia & 13,672 & $24,577,000$ & 139 & $0.256 /$ rank 64 \\
\hline Mauritius & 12,737 & 935,000 & 68.6 & 0.377/rank 80 \\
\hline Mozambique & 861 & $1,718,000$ & 75.8 & 0.582/rank 185 \\
\hline Oman & 25,330 & $1,048,000$ & 103.5 & 0.34/rank 84 \\
\hline Seychelles & 23,172 & 175,000 & 125.6 & Rank 46 \\
\hline Singapore & 53,591 & $9,161,000$ & 274.7 & 0.101/rank 18 \\
\hline South Africa & 9.678 & $8,074,000$ & 54.9 & $0.462 /$ rank 121 \\
\hline Sri Lanka & 4,929 & 654,000 & 48.1 & 0.402/rank 92 \\
\hline Tanzania & 1.334 & 754,000 & 58.8 & 0.566/rank 152 \\
\hline Thailand & 7.633 & $15,936,000$ & 130.4 & 0.36/rank 103 \\
\hline $\begin{array}{l}\text { United Arab } \\
\text { Emirates }\end{array}$ & 42,293 & - & 135.5 & 0.241/rank 41 \\
\hline Yemen & 2,060 & $1,025,000$ & 64.1 & $\begin{array}{l}0.747 / \text { rank } \\
160\end{array}$ \\
\hline
\end{tabular}




\section{Appendix B}

\section{Proposals for IORA Gender Reform}

- IORA countries could prioritise employment opportunities for women, especially building women's livelihoods through vocational education and skills in the areas of trade and tourism

- IORA countries could focus on ensuring women's access to cross borders safely and access markets in safety

- IORA countries could support changes to legislation that encourage women's role in their economies through decent work, in line with CEDAW

- IORA countries could assist women business leaders to lead change in their countries

- IORA countries could integrate gender-specific perspectives at the design stage of policy and programming, especially in relation to trade and tourism

- IORA countries could consider reforms which provide more equitable access for women to assets and services - land, water, technology, innovation and credit, banking and financial services

- IORA countries could consider the growth potential of their creative economies, including textile production

- Infrastructure programmes in IORA nations could be designed to maximise poor women's and men's access to the benefits of roads, transportation services, telecommunications, energy and water, to allow them to participate in the formal economy

- IORA countries could help enhance the capacities of women entrepreneurs to sell goods and services in new markets (domestic and international) and expand sales in existing markets; including through state-sponsored IORA festivals, showcases and trade fairs, encouraging them to export, participate in local and global supply chains, and take advantage of government procurement programs where feasible

- IORA countries could commit to deliver functional adult literacy relevant to trade delivered at workplaces, coupled with more childcare facilities.

- IORA countries could consider a structured program of policy development and gender-aware capacity building for cultural and creative industries, with a focus on tourism and textiles, as part of their 'creative economy' plan

- IORA countries could provide incentives for women to navigate regulatory and legal environment relevant to trade and tourism in their system. For example, IORA countries could set a voluntary target for women accessing institutional regulatory regimes for trade and tourism — such as $20 \%$ increase in women getting relevant permits, or access to grants, or access to ports, or gender targets in procurement policies, or $20 \%$ more women accessing STEM training.

- IORA countries could support women's associations and collective action in the areas of trade and tourism. 
- IORA countries could develop Gender-Sensitive Trade Policy, based on UNCTAD precedents, for example:

- Incorporating gender components in Aid-for-Trade and other development assistance mechanisms

- Gender analysis in the configuration of trade agreements

- Assessing gender-related impacts of a trade agreement before adoption

- IORA countries could develop Gender-Aware Tourism Development Strategies, as part of their 'creative economy' plan.

- IORA countries could consider a pilot scheme to help informal women traders move into the formal economy.

- IORA countries could support female entrepreneurship and set specific programs to help women overcome business start-up obstacles and expand their businesses, including, inter alia, improving their access to credit and other means of production, providing training on business strategy, management, operation, marketing, etc. making information on trade policies, market opportunities and regulatory environments in IORA economies available to women, and offering relevant support services and facilities.

- The IORA Grouping could develop a workshop of this nature that could travel the region.

- IORA countries could volunteer to develop a pilot of a Safe Market/Safe Port Access program.

- IORA countries could help to enhance capacities of women entrepreneurs to sell goods and services in new markets and expand sales in existing markets, including by statesponsored IORA showcases and trade fairs, encouraging them to export, participate in local and global supply chains and take advantage of government procurement programs, where feasible.

- IORA countries could support the development of e-commerce, encourage and train women to make use of ICT for self-employment and to start and grow their businesses, and to engage in regional trade cooperation.

- IORA countries could encourage women to set up and participate in various business networks to form new business partnerships with both men and women, including business mentor-protégé relationships.

- IORA countries could support the launch of an IORA regional women's entrepreneurship network or networks to assist women entrepreneurs in all IORA economies in better connecting to each other, and expanding their channels and opportunities to engage in regional trade and economic cooperation.

- IORA countries could consider developing vocational education programs on entrepreneurship.

- IORA countries could support broad-based effective participation of women and women's groups in trade consultations and negotiations as well as in trade policymaking and related implementation. 
- The IORA Grouping could facilitate the exchange of views and experiences among women engaged in trade negotiations and policy formulation and implementation.

- The IORA Grouping could facilitate contacts, coaching and sharing of experiences among women entrepreneurs.

- The IORA Grouping could facilitate the linkages between women-owned/managed micro and small enterprises and larger national or multinational firms. It could link women engaged in boutique tourism to international tourism operators. 


\section{References}

Aguirre, DeAnne, Leila Hoteit, Christine Rupp, and Karim Sabbagh, 2012, "Empowering the Third Billion. Women and the World of Work in 2012,” Booz and Company.

Azevedo, Roberto, 2014. 'Let's Make Sure 2015 Will Be a Year to Remember for the WTO' (speech to WTO General Council, 10 December), http://www.wto.org/english/news_e/news14_e/gc_rpt_10dec14_e.htm.

Bandiera, O. and A. Natraj, 2013, "Does Gender Inequality Hinder Development and Economic Growth? Evidence and Policy Implications,” The World Bank Research Observer.

Barsh, J., and L. Yee, 2012, “Unlocking the Full Potential of Women at Work,” McKinsey \& Company/Wall Street Journal.

Beeson, Mark and Richard Higgott 2014. 'The changing architecture of politics in the AsiaPacific: Australia’s middle power moment?' International Relations of the Asia-Pacific 14 (2014): 215-237.

Blackden, M., and Mary Hallward-Driemeier, 2013, “Ready to Bloom?” Finance \& Development (June), International Monetary Fund.

Campbell, D., and I. Ahmed, 2012, “The Labour Market in Developing Countries,” September 19. http://www.iza.org/conference_files/worldb2012/campbell_d2780.pdf.

Catalyst, 2004, “The Bottom Line: Connecting Corporate Performance and Gender Diversity," Catalyst, New York, San Jose, and Toronto.

CEDA 2015. Global networks: transforming how Australia does business. ISBN: 085801 3029 , available at http://adminpanel.ceda.com.au/FOLDERS/Service/Files/Documents/28469 GlobalNet works_researchreport.pdf

Coates, J.M., and J. Herbert, 2008, "Endogenous Steroids and Financial Risk Taking on a London Trading Floor,” PNAS, Vol. 105, No. 15: 6167-172.

Dadush, Uri, 2015. 'What Should Be Done About the Great Trade Slowdown?' CEIP op ed, http://carnegieendowment.org/2015/08/19/what-should-be-done-about-great-tradeslowdown/iew5, 19 August.

Department of Foreign Affairs and Trade. 2014. "Paths to Women's Economic Empowerment: Tourism and Textiles in IORA Countries.” Government of Australia, Canberra. http:// www.iora.net/media/149928/australian_hosted_iora_event_on_women_s_economic_e mpowerment_17-19_august_2014.pdf

De Schutter, Olivier and Kaitlin Cordes, 2014. 'Trading Away Human Rights', Project Syndicate, http://www.project-syndicate.org/commentary/olivier-de-schutter-andkaitlin-y--cordes-demand-that-the-trans-pacific-partnership-s-terms-be-subject-to-ahuman-rights-impact-assessment\#dJcxuq3x81vXwd6d.01, 7 January.

Draper, Peter and Salim Ismail, 2014. 'Sitting on the sidelines: How will mega-regionals affect African LDCs?’ Bridges Africa http://www.ictsd.org/bridges-news/bridges- 
africa/news/sitting-on-the-sidelines-how-will-mega-regionals-affect-african, 1 December.

Elborgh-Woytek, Katrin, Monique Newiak, Kalpana Kochhar, Stefania Fabrizio, Kangni Kpodar, Philippe Wingender, Benedict Clements, and Gerd Schwartz, 'Women, Work, and the Economy: Macroeconomic Gains From Gender Equity’, IMF Staff Discussion Note September 2013, available at https://www.imf.org/external/pubs/ft/sdn/2013/sdn1310.pdf, accessed 2 June 2014.

Galinsky, Adam D., Andrew R. Todd, Astrid C. Homan, Katherine W. Phillips, Evan P. Apfelbaum, Stacey J. Sasaki,Jennifer A. Richeson, Jennifer B. Olayon, and William W. Maddux. 2015. 'Maximizing the Gains and Minimizing the Pains of Diversity: A Policy Perspective’ Perspectives on Psychological Science, November 10: 742-748.

Gollo, Ann Marie, Anju Malhotra, Priya Nanda and Rekha Mehra, Understanding and Measuring Women's Economic Empowerment: definition, framework and indices (the International Center for Research on Women (2011, Washington).

G20 Turkey 2015. Prospects for Global Trade. IMF and World Bank, May. Available at http://g20.org/English/Documents/PastPresidency/201512/t20151228_2060.html

Grattan Institute, Game-Changers: Economic reform priorities for Australia, Melbourne, 2012.

Heinz 2006.

IORA website. 'Gender Empowerment'. Available at http://www.iora.net/about-us/priorityareas/gender-empowerment.aspx

InterParliamentary Union. Women in Politics Map 2014. Available at http://www.ipu.org/pdf/publications/wmnmap14_en.pdf

Lehmann, Jean-Pierre 2015. The WTO, TPP, $21^{\text {st }}$ century global trade mess and the poverty of nations, Forbes http://www.forbes.com/sites/jplehmann/2015/08/03/the-tpp-the-wtothe-21st-century-global-trade-mess-and-the-poverty-of-nations/, 3 August.

Lowy Institute, 2013. G20 Monitor: Trade and the G20. Available at http://www.lowyinstitute.org/publications/trade-and-g20, 2 June.

Lückerath-Rovers, Mijntje 2013. 'Women on boards and firm performance' Journal of Management \& Governance, May 2013, Volume 17, Issue 2, pp 491-509.

Marston, Ama 2015. 'Enabling Women's Contributions to the Indian Ocean Rim Economies' UN Women. Available at: http://www.unwomen.org/en/digitallibrary/publications/2015/9/enabling-womens-contributions-to-the-indian-ocean-rimeconomies\#sthash.4Vt8D0FV.dpuf

McCormick, Hamish, 2015. 'Beyond FTAs: Why the World Trade Organisation Still Matters.' Presentation to Australian Institute of International Affairs (Queensland), 17 August.

G20, G20 Mexico Leaders’ Declaration, Los Cabos, 18-19 June 2012, available at http://g20watch.edu.au/g20-leaders-declaration-los-cabos-2012.

${ }^{1}$ G20, G20 Russia Leaders' Declaration, St Petersburg, 5 September 2013, available at http://www.mofa.go.jp/files/000013493.pdf. 
${ }^{1}$ Available at http://www.gpfi.org/about-gpfi

${ }^{1}$ G20, G20 Australia Leaders’ Communiqué, Brisbane, 15-16 November 2014, http://www.g20australia.org/sites/default/files/g20_resources/library/brisbane_g20_lead ers_summit_communique.pdf.

${ }^{1}$ Susan Harris Rimmer, "Why the W20? Reasons to Take the Newest G20 Social Partner Seriously”, 10 November 2015, http://www.usak.org.tr/en/usakanalysis/comments/why-the-w20-reasons-to-take-the-newest-g20-social-partnerseriously.

${ }^{1}$ W20, Women's Summit Communiqué, G20 Turkey, Istanbul, 17 October 2015, http://www.g20.utoronto.ca/2015/151017-w20.html.

OECD, 'Women's economic empowerment', The OECD DAC Network on Gender Equality (Gendernet). 2012, available at www.oecd.org/dac/povertyreduction/50157530.pdf, accessed 1 June 2014.

Pelosi, Nancy 2015. 'Nancy Pelosi: Trade promotion authority on its last legs’ USA Today, 15 June.

Phillips, Andrew (2013): Australia and the challenges of order-building in the Indian Ocean region, Australian Journal of International Affairs, 67:2, 125-140.

UN Women. Global Report on Women in Tourism 2010. http://www.unwomen.org/ /media/Headquarters/Media/Stories/en/folletoglobarlreportp df.pdf

UN Women, Tourism a Vehicle for Gender Equality and Women’s Empowerment, 2011, available at: http://www.unwomen.org/en/news/stories/2011/3/tourism-a-vehicle-forgender-equality-and-women-s-empowerment/\#sthash.JePMWi02.pdf

UN Womenwatch, Gender Equality \& Trade Policy, 2011, available at http://www.un.org/womenwatch/feature/trade/gender_equality_and_trade_policy.pdf

Were, Maureen and Jane Kiringai, 2004. Gender Mainstreaming In Macroeconomic Policies and Poverty Reduction Strategy in Kenya, Kenya Institute for Public Policy Research and Analysis, available at http://www.sarpn.org/documents/d0000832/index.php.

Wesley, Michael 2015. 'Trade agreements and strategic rivalry in Asia', Australian Journal of International Affairs, Special Issue: Australian Trade Policy: A Decade on from the Australia-US Free Trade Agreement, 69(5): 479-495.

World Bank. Gender at Work. 2013, available at http://www.worldbank.org/content/dam/Worldbank/Event/Gender/GenderAtWork_web 2.pdf

World Bank. World Development Report 2012: Gender Equality and Development, available at http://econ.worldbank.org/WBSITE/EXTERNAL/EXTDEC/EXTRESEARCH/EXTW DRS/EXTWDR2012/0,,menuPK:7778074 pagePK:7778278 piPK:7778320 theSiteP K:7778063 contentMDK:22851055,00.html 
World Trade Organization, International Trade Statistics 2012, available at www.wto.org/english/res_e/statis_e/its2012_e/its2012_e.pdf, accessed 1 June 2014.

World Trade Organization, 2014, World Trade Report https://www.wto.org/english/res_e/publications_e/wtr14_e.htm. Accessed 5 March 2016.

World Trade Organization, 2015, Regional Trade Agreements Information System. http://rtais.wto.org/ui/PublicAllRTAList.aspx. Accessed 5 March 2016. 